\title{
Evaluation of Mesh of Liberation of Zard Koh and Kulli Koh Iron Ores of Pakistan
}

\author{
SULTAN AHMED KHOSO*, MUHAMMAD ISHAQUE ABRO**, AND MUHAMMAD HASSAN AGHEEM*** \\ RECEIVED ON 18.01.2017 ACCEPTED ON 12.02.2018
}

\begin{abstract}
Liberation size plays a significant role to select a correct and successful concentration method for natural iron ores. This paper aims to evaluate the liberation size of two newly discovered iron ores, namely Zard Koh and Kulli Koh, existing in Chagai region of Pakistan. Zard Koh iron ore is mainly composed of maghemite along with the pyrite, chlorite, grossular and admontite as gangue minerals, whereas, Kulli Koh iron ore is comprised of hematite mostly with quartz, dravite and kaolinite as the gangue minerals. The representative samples of ores were pulverized and sieved to different size fractions. The liberation size of iron bearing minerals and gangues was investigated by analyzing the different size fractions of each ore using XRF (X-Ray Fluorescence), SEM (Scanning Electron Microscope) attached with EDS (Energy Dispersive Spectroscope). The XRF results revealed that the most probable liberation size of Zard Koh and Kulli Koh ores is most likely existing at $-75+45$ and $-150+106 \mu \mathrm{m}$, respectively. In order to confirm this liberation size, further evidences were collected using SEM and EDS examinations. It is interesting to note that the results obtained from SEM and EDS were quite in agreement with XRF results.
\end{abstract}

Key Words: Mesh of Liberation, Chagai, Maghemite, Grossular, Dravite, Kaolinite.

\section{INTRODUCTION}

$\mathrm{T}$ The naturally occurring ore bodies containing valuable metals commonly intergrown with gangues. For their efficient separation from each other, a sufficient liberation is required [1-2]. The liberation size, sometimes also known as mesh of liberation, is the optimal size at which substantially all of the valuable gangue minerals are detached from valuable minerals [34]. Crushing and grinding are two consecutive methods to achieve the equal liberation of an ore [2,5]. Literature review indicates that the liberation size plays a significant role to select a right and successful concentration method for a natural iron ore body [1,3,6-9]. It can be seen from the Fig. 1 that all concentration methods for a particular ore deposit depend on its mineral liberation size [3]. Furthermore, the precise information of liberation size is imperative for designing the comminution circuit otherwise either overgrinding or incomplete of ore will result $[3,10$ $11]$.

Authors E-Mail: (sultan.khoso@faculty.muet.edu.pk, ishaque.abro@faculty.muet.edu.pk, mhagheem@usindh.edu.pk) * Department of Mining Engineering, Mehran University of Engineering \& Technology, Jamshoro.

** Department of Metallurgy \& Materials Engineering, Mehran University of Engineering \& Technology, Jamshoro.

*** $\quad$ Center for Pure and Applied Geology, University of Sindh, Jamshoro.

This is an open access article published by Mehran University Research Journal of Engineering and Technology, Jamshoro under the CC by 4.0 International License. 
Nowadays the advanced technology, especially electronics and computing technology, is being used for the assessment of an accurate mineral liberation size. Different analytical techniques, including elemental and image analysis, have been used for the determination of liberation size of a natural ore body [12-13]. Many researchers applied XRF, SEM with EDS, TEM (Transmission Electron Microscope), and SM (Stereo Microscope) to measure the mesh of liberation of mineral grains $[3,7,14-15]$. The procedure adopted by several investigators $[3-4,7-8,11,16]$ suggested that the elemental and image analysis of various size fractions of a particular ore is required to identify the liberation size.

In XRF analysis, the size fraction which advocated substantial increase in the grade is considered as the liberation size [3,7-8]. The SEM and EDS analysis are carried out to examine the depth of impurities intergrown with $\mathrm{Fe}_{2} \mathrm{O}_{3}$ host minerals using point analysis chemistry to grains of various size fractions $[3,7-8,11]$. The stable BSE (Back-Scattered Electron) signals from the modern SEM are used to generate quality images, from which the most important minerals can be differentiated through image analysis methods [3]. Sometimes, the mapping techniques of SEM attached with EDS have also been applied [7]. The utmost benefit of these analytical

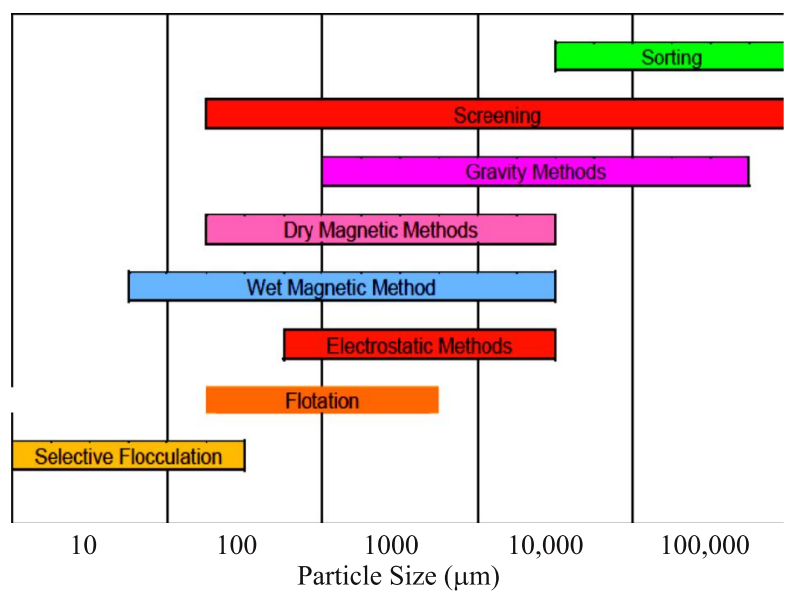

FIG. 1. INFLUENCE OF PARTICLE SIZE ON SELECTION OF CONCENTRATION METHODS [3] techniques is that the investigator can easily determine the liberation size of the desired mineral and gangue grains exist in the ore body $[3,8]$.

Keeping in view the importance of liberation size in the selection of right concentration method and designing of process flow sheet, the efforts were taken to investigate the liberation size of two newly discovered iron ore deposits, namely Zard Koh and Kulli Koh ores, for their beneficial use in iron and steel manufacturing industries. Khoso et. al. [1] and Khoso [4] investigated that the mineralogy of Zard Koh and Kulli Koh iron ores. Mineralogical investigations revealed that Zard Koh ore is containingmaghemite, pyrite, chlorite, grossular and admontite as major minerals, whereas, the Kulli Koh ore is composed mainly of hematite, quartz, dravite, and kaolinite minerals. It is also reported by Khoso et. al. [1] that hematite and maghemite to be the major iron bearing minerals in Kulli Koh and Zard Koh ores are paramagnetic and ferromagnetic in nature, respectively. Further, the quartz in Kulli Koh and pyrite in Zard Koh are major gangue minerals and both are diamagnetic in nature. The chemical and mineralogical composition suggested that the $\mathrm{S}$ (Sulfur) from pyrite $\left(\mathrm{FeS}_{2}\right.$ ) and $\mathrm{Si}$ (Silicon) from quartz $\left(\mathrm{SiO}_{2}\right)$ are major impurities in Zard Koh and Kulli Koh iron ores, so their reduction is needed as per the requirement of smelter operator. In present work, liberation size of Zard Koh and Kulli Koh iron ores was successfully investigated and the results and findings are presented in this paper.

\section{MATERIALS AND METHOD}

\subsection{Ore Samples}

Representative samples of each ore were provided by the PSM (Pakistan Steel Mill), Karachi, Pakistan. Zard Koh and Kulli Koh are newly iron ore deposits existing in the Chagai district of Balochistan, Pakistan. As received samples were in the form of large lumps with particle size greater than $7 \mathrm{~cm}$.

Mehran University Research Journal of Engineering \& Technology, Volume 37, No. 4, October, 2018 [p-ISSN: 0254-7821, e-ISSN: 2413-7219] 


\subsection{Sample Preparation and Analysis Techniques}

The samples of each ore were pulverized and sieved to different size fractions. Laboratory jaw crusher was used to pulverize the large lump of ores and the gap between jaws was set to $2 \mathrm{~mm}$. Laboratory sieve shaker was used to obtain the different size fractions of the pulverized ores. Thereafter, the representative samples from each size fraction were prepared for XRF and SEM-EDS analysis by using coning and quartering technique of sampling. The operating factors of XRF, SEM and EDS analysis used in present study are reported elsewhere [4]. The image and elemental analysis techniques were exploited for the determination of liberation size of ores. PAN alytical XRF equipment (Model AXIOX) was used for elemental analysis of different size fractions. For this, the samples of each size fraction were pulverized to very ultrafine powders and then beats were prepared using Lithium-tetraborate ( $\mathrm{Li} 2 \mathrm{~B} 4 \mathrm{O} 7)$. The ratio of sample to Li2B4O7 was set at 1:8. The SEM (Model: JEOL JSM6380LV) attached with EDS was used forthe image analysis of coarser to ultrafine grains. Through SEM, the size and chemistry of the mineral grain(s) was investigated using point analysis technique by EDS. Sometimes, the elemental analysis of the whole image was also determined.

\section{RESULTS AND DISCUSSION}

\subsection{Liberation Size of ZardKohDeposits}

The elemental composition of various size fractions of Zard Koh ore is presented in Table 1. The percent distribution of major minerals in each size fraction is shown in Fig. 2. The XRF results demonstrate the increasing and decreasing trend of $\mathrm{Fe}_{2} \mathrm{O}_{3}$ and $\mathrm{FeS}_{2}$, respectively, from the size fraction $-400+300 \mu \mathrm{m}$ down to $-75+45 \mu \mathrm{m}$ (Fig. 2). It is also found that percent distribution of $\mathrm{Fe}_{2} \mathrm{O}_{3}$ and $\mathrm{FeS}_{2}$ significantly reduced and increased in the size fraction below $45 \mu \mathrm{m}$, respectively. XRF results also reveal that the percent distribution of other gangue minerals like $\mathrm{SiO}_{2}, \mathrm{Al}_{2} \mathrm{O}_{3}, \mathrm{CaO}, \mathrm{MgO}$ and $\mathrm{MnO}$ is normally the equivalent in all size fractions from coarser to finer size, and their $\%$ content is quite in range for the blast furnace operations. This meant that excluding pyrite, the other gangues minerals like grossular, admontite and chlorite have no any harmful effect on the smelter operations. Keeping in view the substantial improvement in the grade of ore (i.e. $60.79 \% \mathrm{Fe}_{2} \mathrm{O}_{3}$ ) in $-75+45 \mu \mathrm{m}$ size fraction compared to rest sizes, it was envisaged that liberation size of Zard Koh ore exists in $-75+45 \mu \mathrm{m}$ particle size. In addition, a significant decrease in pyrite content (i.e. $9.02 \% \mathrm{FeS}_{2}$ ) in this size fraction further advocates the suggested liberation size of the ore.

TABLE 1. XRF RESULTS OF VARIOUS PARTICLE SIZES OF ZARD KOH ORE

\begin{tabular}{|c|c|c|c|c|c|c|c|}
\hline \multirow{2}{*}{$\begin{array}{c}\text { Particle Size } \\
(\mu \mathrm{m})\end{array}$} & \multicolumn{9}{|c|}{ Major Elements in Ore } \\
\cline { 2 - 8 } & $\begin{array}{c}\mathrm{Fe}_{2} \mathrm{O}_{3} \\
(\%)\end{array}$ & $\begin{array}{c}\mathrm{FeS}_{2} \\
(\%)\end{array}$ & $\begin{array}{c}\mathrm{SiO}_{2} \\
(\%)\end{array}$ & $\begin{array}{c}\mathrm{Al}_{2} \mathrm{O}_{3} \\
(\%)\end{array}$ & $\begin{array}{c}\mathrm{CaO} \\
(\%)\end{array}$ & $\begin{array}{c}\mathrm{MgO} \\
(\%)\end{array}$ & $\begin{array}{c}\mathrm{MnO} \\
(\%)\end{array}$ \\
\hline$-400+300$ & 37.33 & 15.08 & 6.18 & 1.14 & 4.03 & 2.64 & 0.32 \\
\hline$-300+200$ & 40.80 & 15.16 & 6.15 & 1.26 & 3.39 & 2.2 & 0.35 \\
\hline$-200+106$ & 40.01 & 13.01 & 6.07 & 1.04 & 3.16 & 2.45 & 0.31 \\
\hline$-106+75$ & 43.96 & 12.03 & 6.03 & 1.01 & 3.27 & 2.55 & 0.33 \\
\hline$-75+45$ & 60.79 & 9.02 & 5.03 & 1.15 & 2.71 & 2.004 & 0.32 \\
\hline$-45+30$ & 61.00 & 9.97 & 7.39 & 1.12 & 4.24 & 2.96 & 0.31 \\
\hline-30 & 60.45 & 10.11 & 7.56 & 1.55 & 4.78 & 3.04 & 0.32333 \\
\hline
\end{tabular}

Mehran University Research Journal of Engineering \& Technology, Volume 37, No. 4, October, 2018 [p-ISSN: 0254-7821, e-ISSN: 2413-7219] 
Using SEM and EDS analysis technique, the additional evidences were collected to confirm the liberation size of Zard Koh ore evaluated by XRF analysis. The SEM images of each size fraction of ore (from $-400+300 \mu \mathrm{m}$ down to $-75+45 \mu \mathrm{m}$ ) along with the point chemistry of mineral grains by EDS are presented from Fig. 3(a-e). The point chemistry analysis through the BEI (Back Scattered Images) indicated that the whitish grains are enriched with maghemite, whereas dark grey and light grey grains are enriched with quartz and pyrite minerals respectively. During SEM and EDS analysis, two most important features; population of maghemite (Fe enriched grains) and grade of maghemite, were studied to evaluate the liberation size of Zard Koh ore. Fig. 3(a-e) demonstrate that the majority of maghemite (whitish) grains is extensively increasing with decreasing of particle size from $-400+300 \mu \mathrm{m}$ down to $-75+45 \mu \mathrm{m}$. Furthermore, the point chemistry of whitish grains shows that the grade of maghemite particles is improving at cost of decrease in sulfur when the size of ore was reduced from $-400+300 \mu \mathrm{m}$ down to $-75+45 \mu \mathrm{m}$ (Fig. 3(a-e)). This increase in grade obviously indicates that the concentration of associated gangues like pyrite, grossular, admontite and chlorite was reduced by decreasing the size of maghemite grains. It is interesting to note that the substantial increase in population and grade of maghemite grains is found at particle size of $-75+45 \mu \mathrm{m}$. This meant that the liberation size evaluated by SEM and EDS analysis is in accordance with that envisaged from results of XRF analysis. Therefore, on the basis of XRF, SEM and EDS results, it was concluded that the possible liberation size of pyrite and maghemite in Zard Koh ore exists at $75+45 \mu \mathrm{m}$ particle size range.

\subsection{Liberation Size of Kulli Koh Iron Ore}

XRF results of various particle sizes of the Kulli Koh iron ore is given in Table 2. Fig. 4 shows the mineral distribution in various particle sizes of the ore. XRF results given in Table 2 revealed the up-down trend of $\mathrm{Fe}_{2} \mathrm{O}_{3}$ and $\mathrm{SiO}_{2}$ minerals with reducing the size of ore from $-500+400 \mu \mathrm{m}$ down to $-150+106 \mu \mathrm{m}$, whereas the other minerals are equally distributed in all size fractions (Fig. 4). It can also be seen from Fig. 4 that the content of $\mathrm{Fe}_{2} \mathrm{O}_{3}$ and $\mathrm{SiO}_{2}$ substantially reduced and increased by decreasing the size of ore below $106 \mu \mathrm{m}$, respectively. However, the grade of ore (i.e. $45.51 \% \mathrm{Fe}_{2} \mathrm{O}_{3}$ ) obtained in the size fraction of $-150+106 \mu \mathrm{m}$ is quite better compared to rest size fractions (Table 2 and Fig. 4). Interestingly, the distribution of $\mathrm{SiO}_{2}$ is comparatively higher in all particle sizes excluding $-150+106 \mu \mathrm{m}$ which contains slightly lower $\%$ of $\mathrm{SiO}_{2}$ (i.e. $5.72 \%)$. Therefore, taking into consideration the improvement in ore grade and reduced in the content of $\mathrm{SiO}_{2}$, it was decided that liberation size of Kulli Koh iron ore exists in the particle size of $-150+106 \mu \mathrm{m}$.

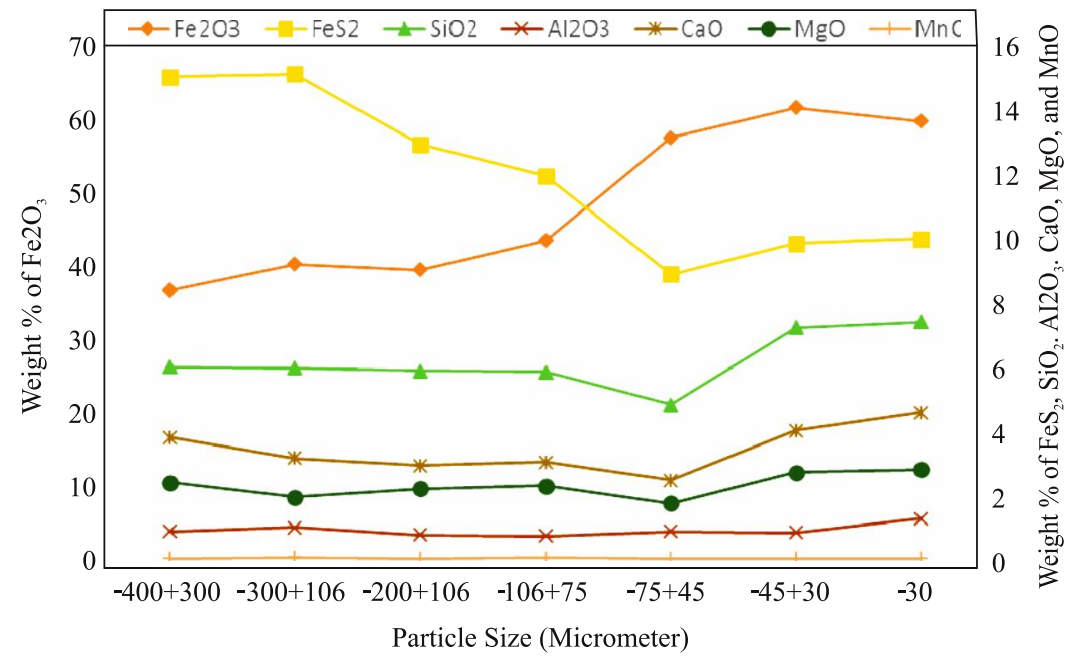

FIG. 2. MINERAL DISTRIBUTION IN VARIOUS PARTICLE SIZES OF ZARD KOH ORE

Mehran University Research Journal of Engineering \& Technology, Volume 37, No. 4, October, 2018 [p-ISSN: 0254-7821, e-ISSN: 2413-7219] 


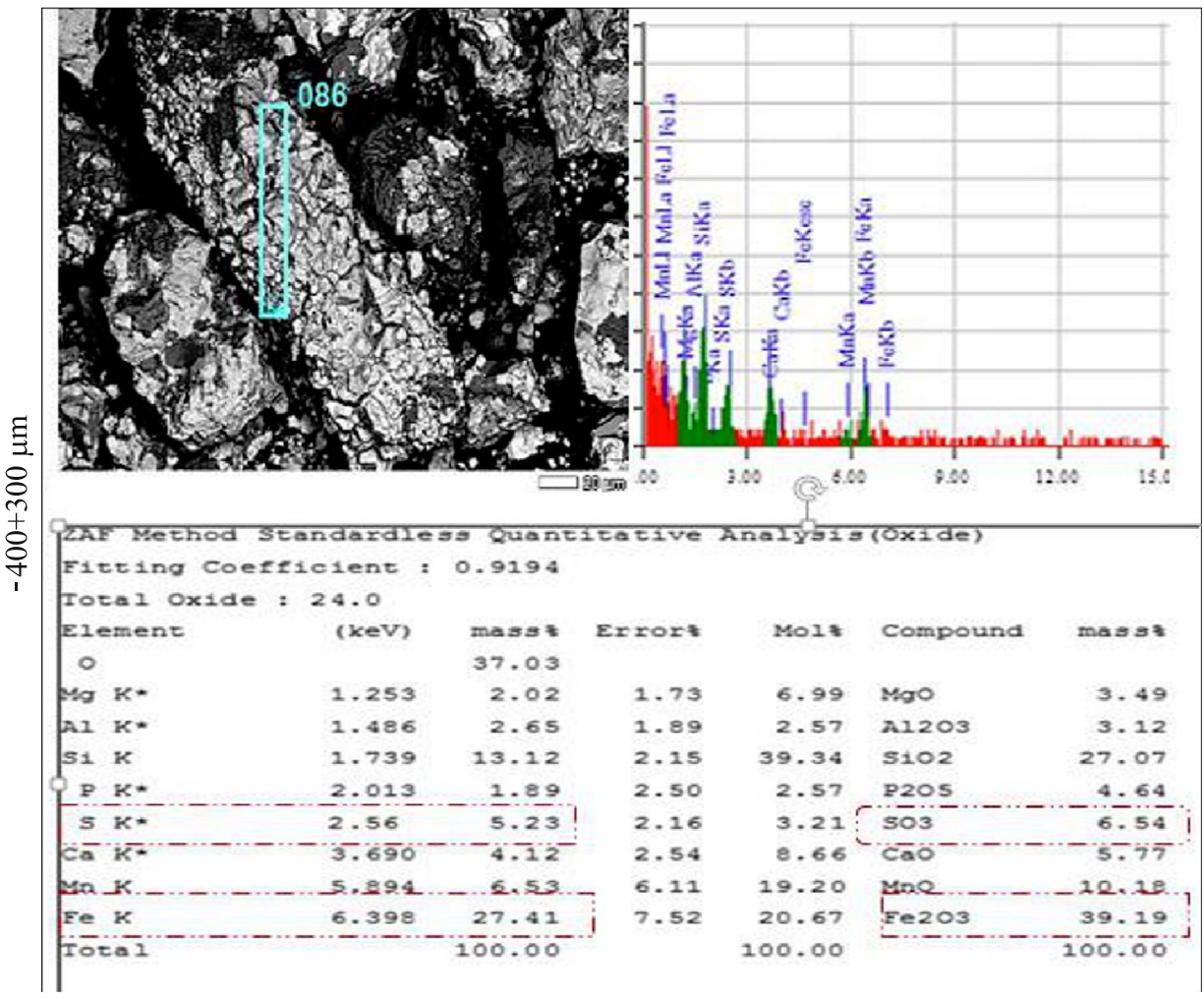

FIG. 3(a). SEM-EDS SPECTRA AND GRADE OF $-400+300 \mu \mathrm{m}$

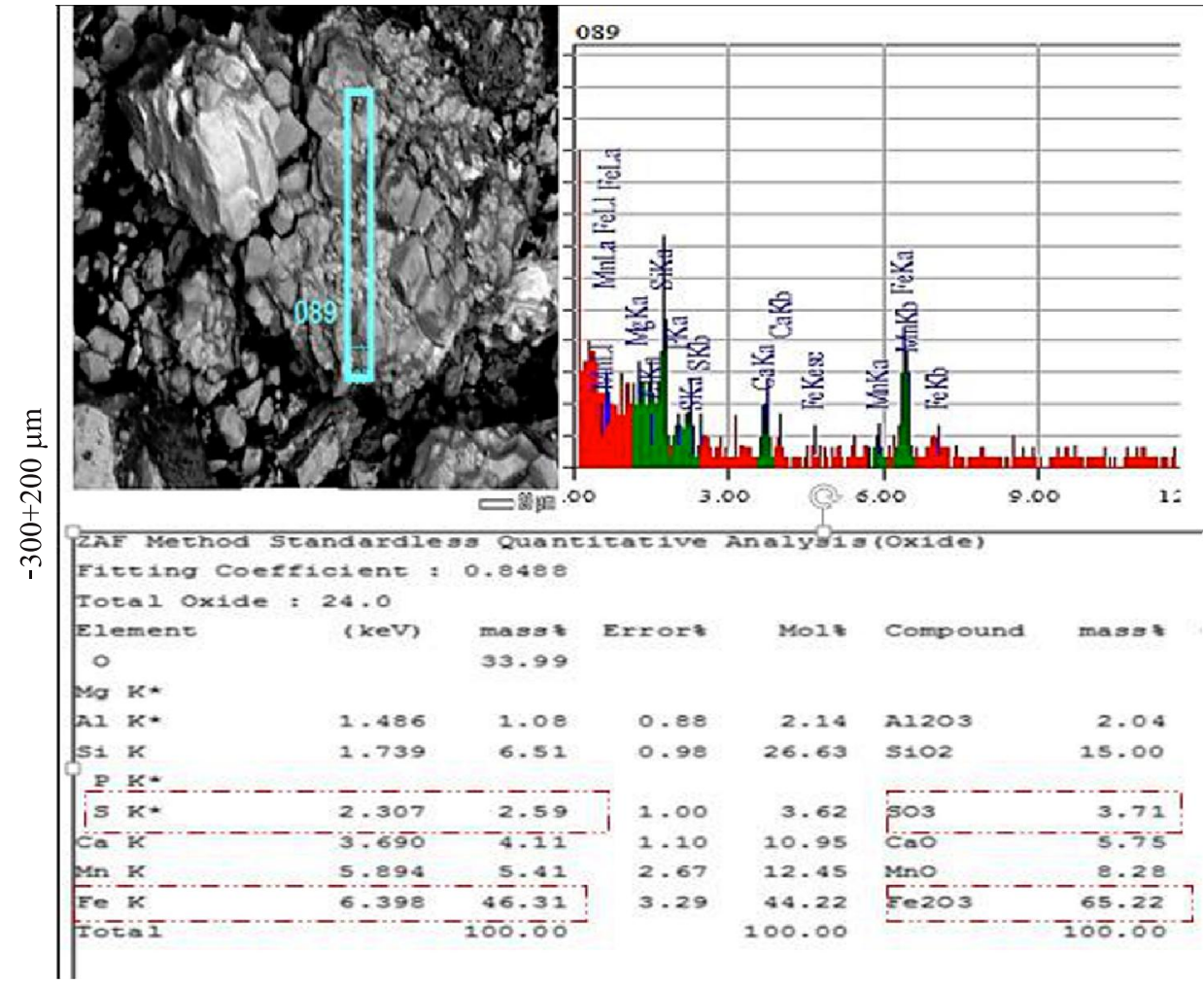

FIG. 3(b). SEM-EDS SPECTRA AND GRADE OF -300+200 $\mu \mathrm{m}$

Mehran University Research Journal of Engineering \& Technology, Volume 37, No. 4, October, 2018 [p-ISSN: 0254-7821, e-ISSN: 2413-7219] 


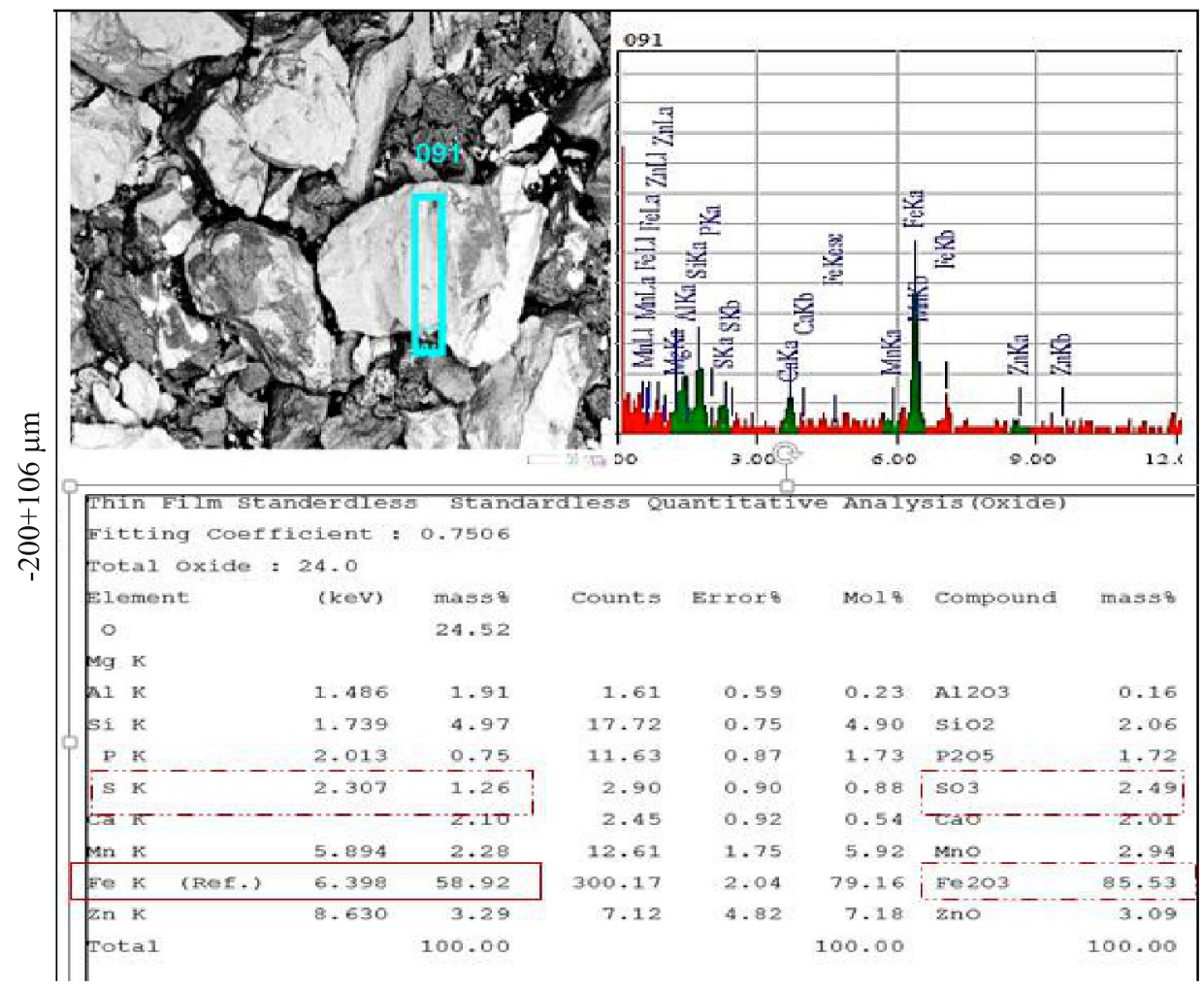

FIG. 3(c). SEM-EDS SPECTRA AND GRADE OF -200+106 $\mu \mathrm{m}$

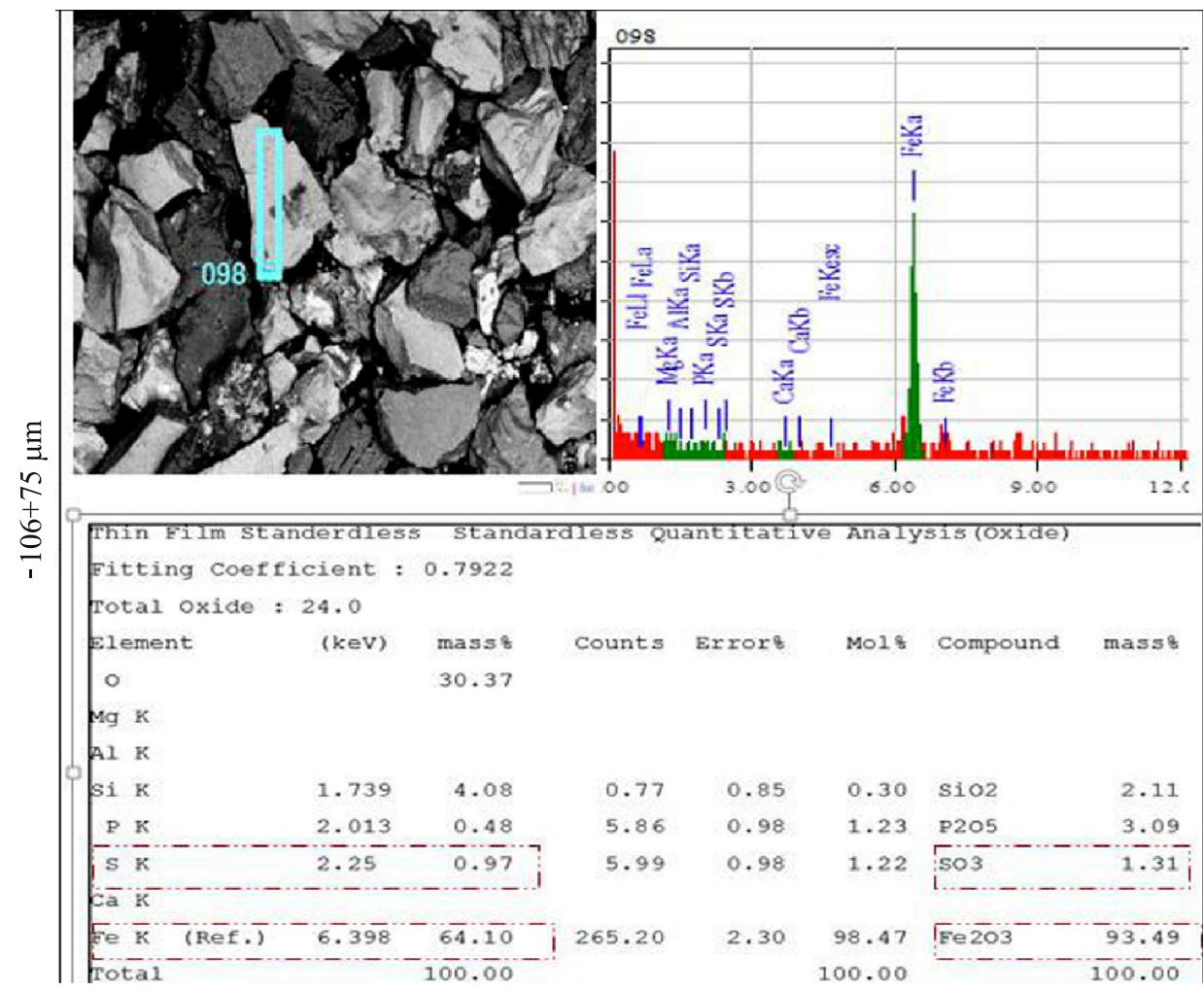

FIG. 3(d). SEM-EDS SPECTRA AND GRADE OF $-106+75 \mu m$ 
The liberation size of Kulli Koh ore evaluated from XRF results was further confirmed from the evidences obtained using the SEM and EDS analysis. SEM images along with EDS point analysis of different size fractions are presented from Fig. 5(a-d). The point chemistry analysis through the BEIindicated that the whitish phases are enriched with hematite grains (Fe rich particles), whereas dark grey grains are enriched with quartz minerals (Si rich particles). The same rule; the population and grade of hematite grains, was applied to assess the liberation size of Kulli Koh iron ore deposit. The SEM images from Fig. 5(a-d) demonstrate that the majority of whitish particles (hematite grains) is much greater in Fig. 5(d) as compared to rests. This implies that the liberation size of hematite phases is averagely improved with decreasing the size of ore up to $150+106 \mu \mathrm{m}$. Besides population, the increasing trend of ore grade was also observed with reduction of ore size

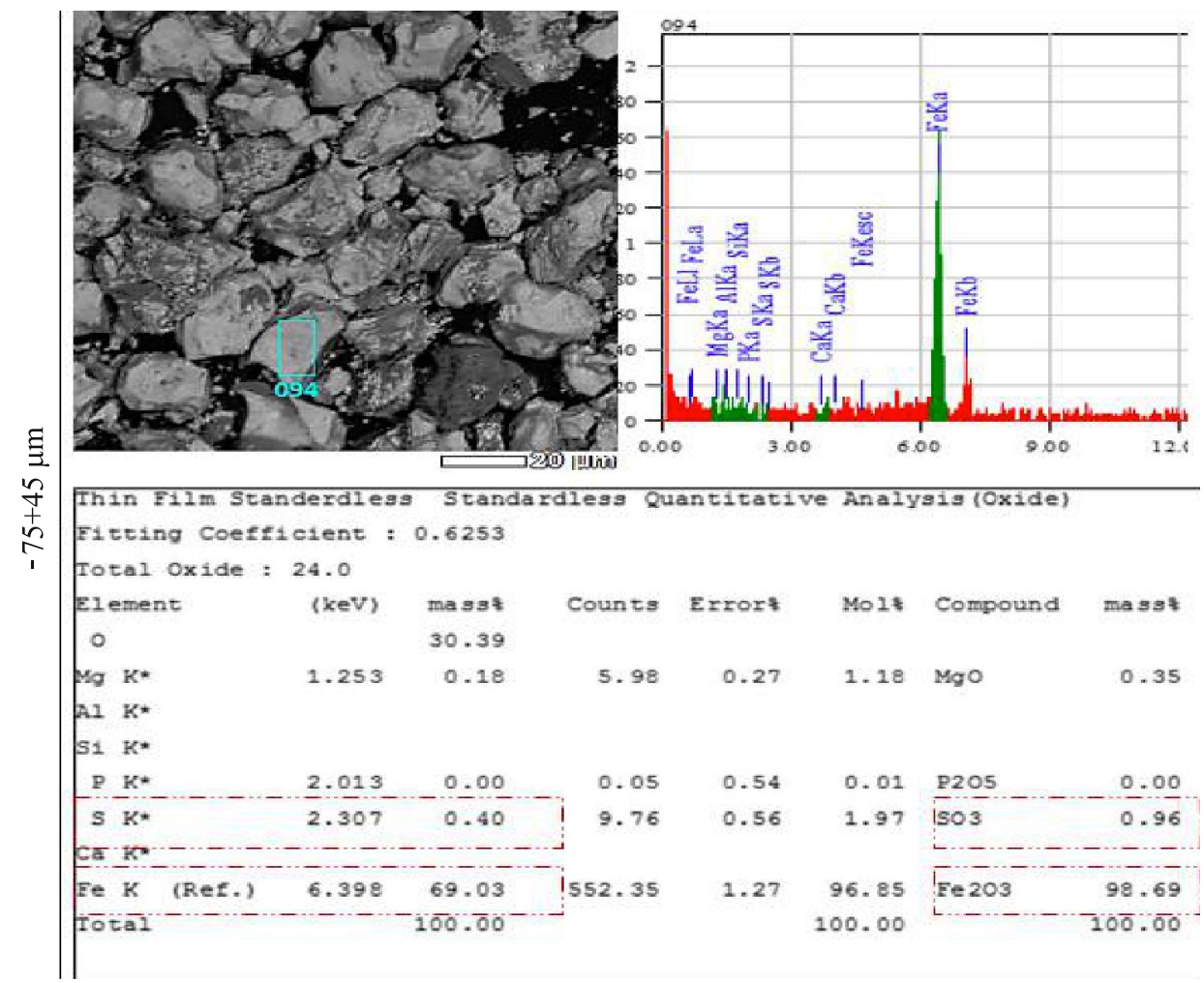

FIG. 3(e). SEM-EDS SPECTRA AND GRADE OF- $75+45 \mu \mathrm{m}$

FIG. 3. SEM IMAGES WITH EDS SPECTRA OF VARIOUS SIZE FRACTIONS OF ZARD KOH ORE

TABLE 2. XRF ANALYSIS OF VARIOUS PARTICLE SIZES OF KULLI KOH ORE

\begin{tabular}{|c|c|c|c|c|c|c|}
\hline \multirow{2}{*}{$\begin{array}{c}\text { Particle Size } \\
(\mu \mathrm{m})\end{array}$} & \multicolumn{9}{|c|}{\begin{tabular}{c} 
Major Elements in Ore \\
\cline { 2 - 7 }
\end{tabular}} & $\begin{array}{c}\mathrm{Fe}_{2} \mathrm{O}_{3} \\
(\%)\end{array}$ & $\begin{array}{c}\mathrm{SiO}_{2} \\
(\%)\end{array}$ & $\begin{array}{c}\mathrm{Al}_{2} \mathrm{O}_{3} \\
(\%)\end{array}$ & $\begin{array}{c}\mathrm{CaO} \\
(\%)\end{array}$ & $\begin{array}{c}\mathrm{MgO} \\
(\%)\end{array}$ & $\begin{array}{c}\mathrm{MnO} \\
(\%)\end{array}$ \\
\hline$-500+400$ & 40.1 & 12.51 & 3.27 & 2.59 & 1.14 & 0.28 \\
\hline$-400+300$ & 39.47 & 11.24 & 3.23 & 3.46 & 1.16 & 0.27 \\
\hline$-300+150$ & 40.55 & 6.88 & 2.87 & 3.17 & 1.01 & 0.24 \\
\hline$-150+106$ & 45.51 & 5.72 & 3.68 & 2.95 & 1.22 & 0.32 \\
\hline$-106+45$ & 44.858 & 6.198 & 3.302 & 3.608 & 1.472 & 0.278 \\
\hline-45 & 43.44 & 6.98 & 3.78 & 4.22 & 2.11 & 0.34 \\
\hline
\end{tabular}

Mehran University Research Journal of Engineering \& Technology, Volume 37, No. 4, October, 2018 [p-ISSN: 0254-7821, e-ISSN: 2413-7219] 
from $-500+400 \mu \mathrm{m}$ down to $-150+106 \mu \mathrm{m}$ (Fig. 5(a-d)). Therefore, keeping in view the maximum majority and grade of hematite particles at $-150+106 \mu \mathrm{m}$ particle size (Fig. 5(d)), it was suggested that most likely the liberation size of Kulli Koh ore is existing in $-150+106 \mu \mathrm{m}$ particle size. Hence all evidences, collected from the XRF, SEMEDS analysis, advocated the liberation size of Kulli Koh iron ore at $-150+106 \mu \mathrm{m}$ particle size.

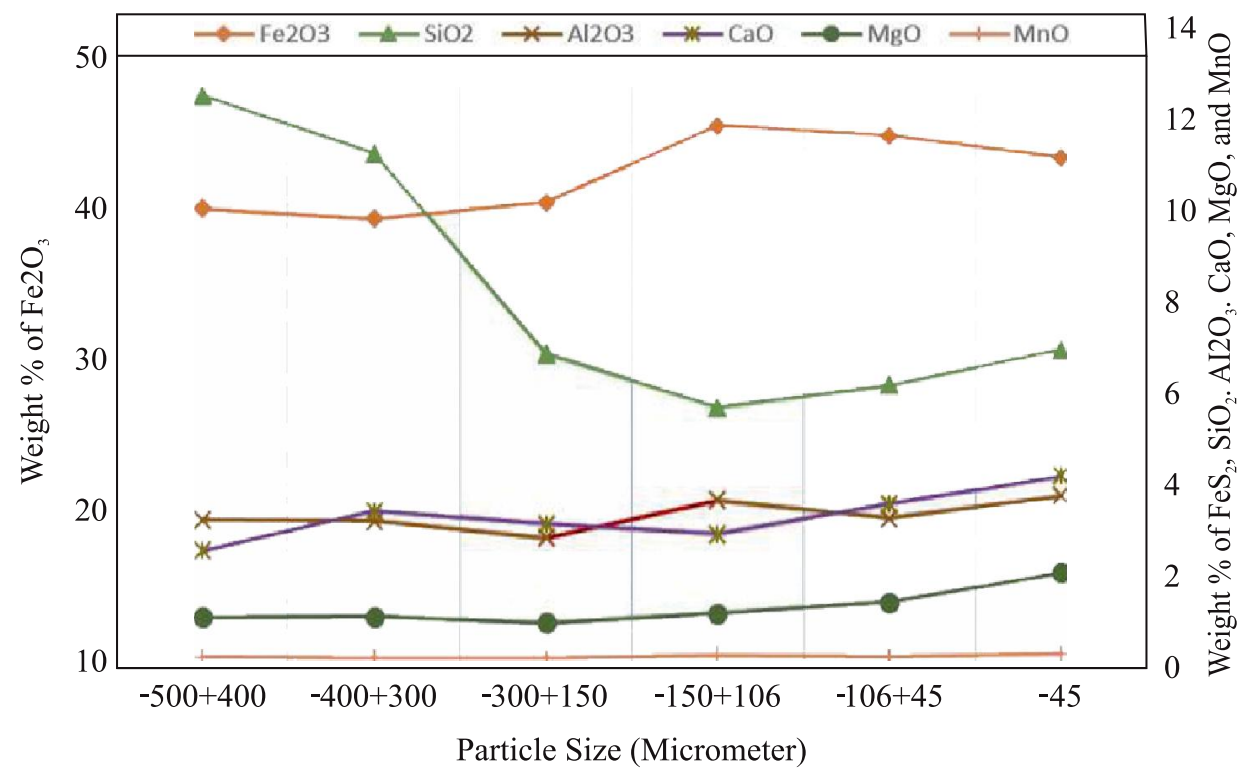

FIG. 4. MINERAL DISTRIBUTION IN VARIOUS PARTICLE SIZES OF KULLI KOH ORE

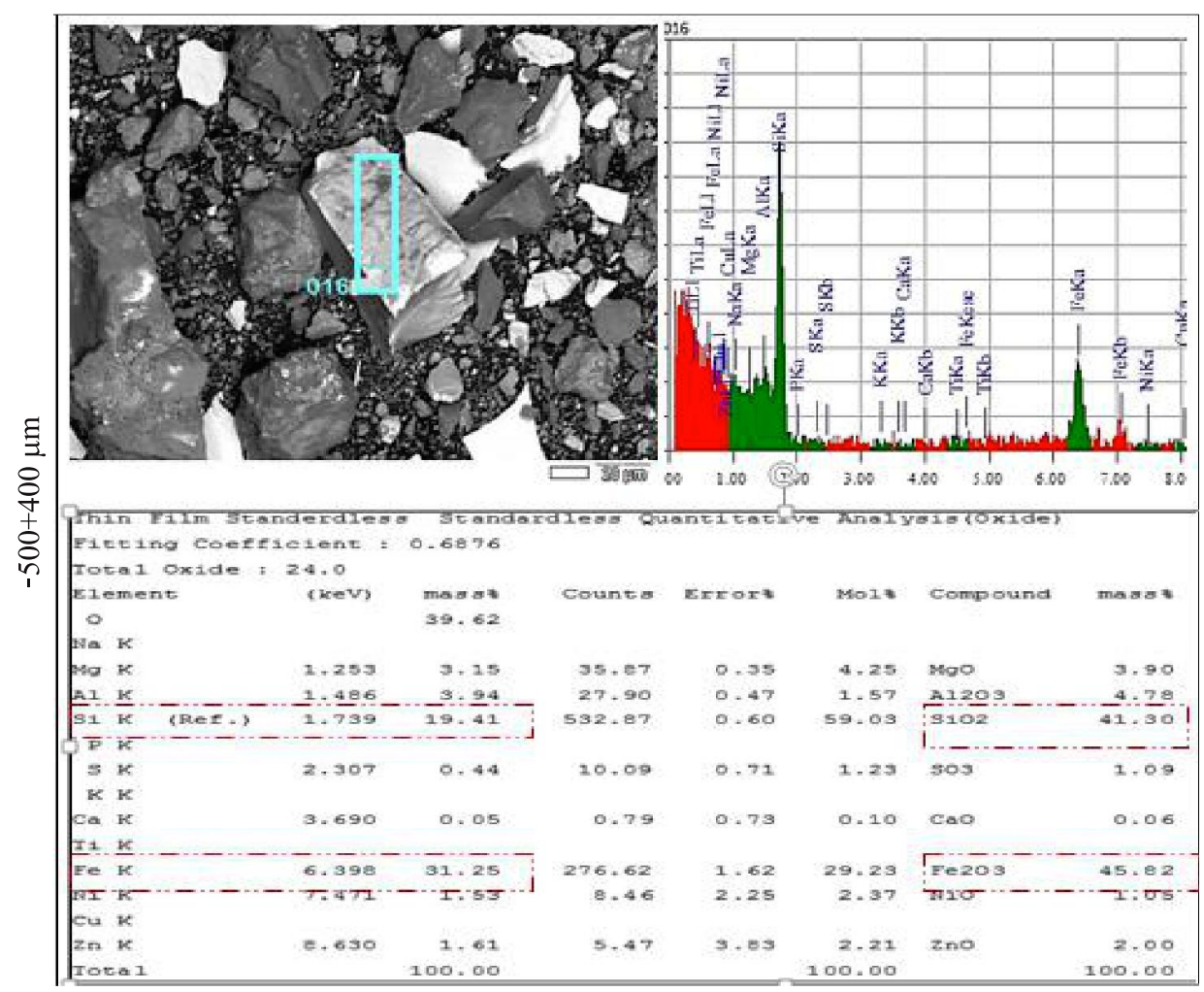

FIG. 5(a). SEM-EDS SPECTRA AND GRADE OF -500+400 $\mu \mathrm{m}$ 


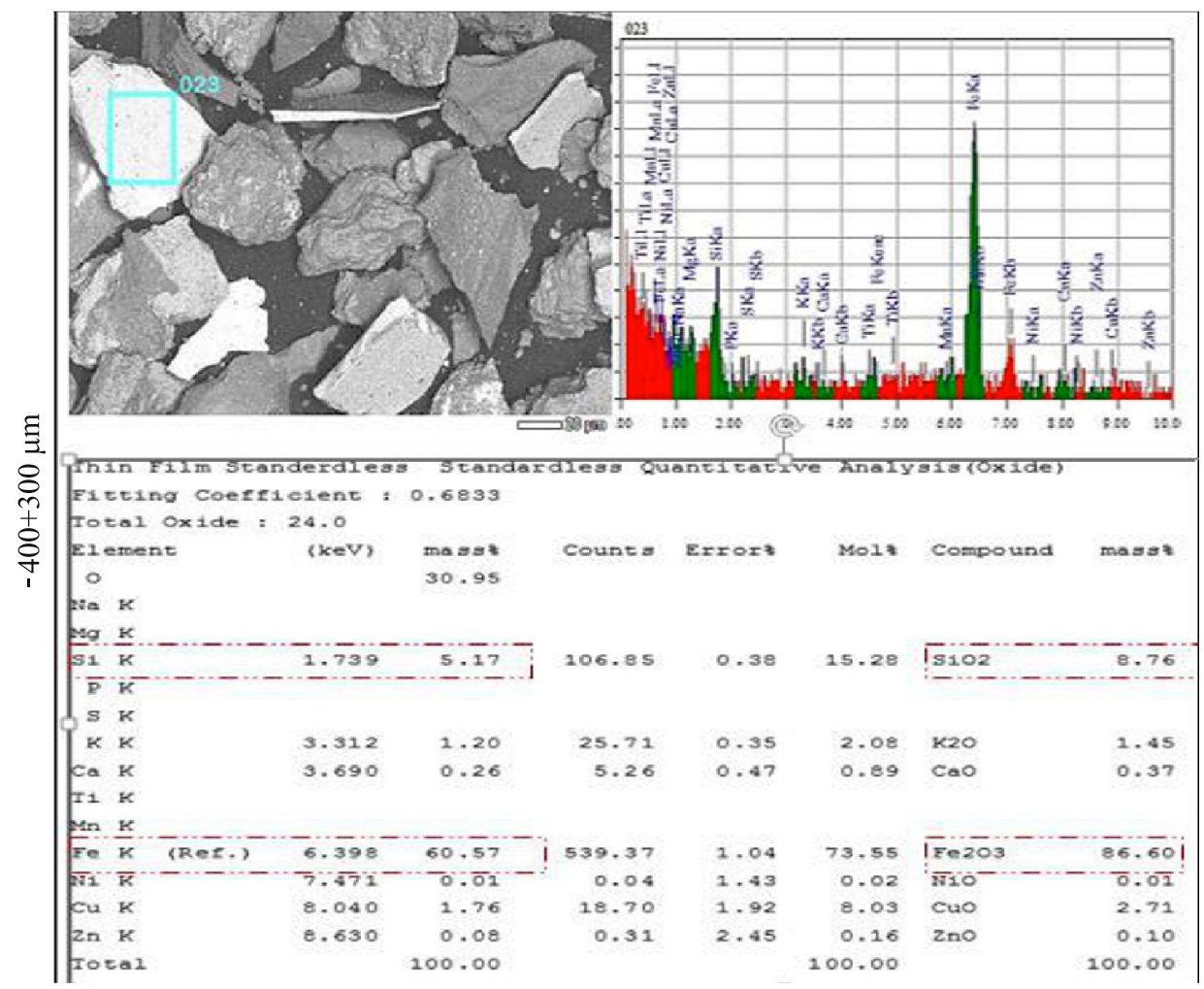

FIG. 5(b). SEM-EDS SPECTRA AND GRADE OF $-400+300 \mu \mathrm{m}$

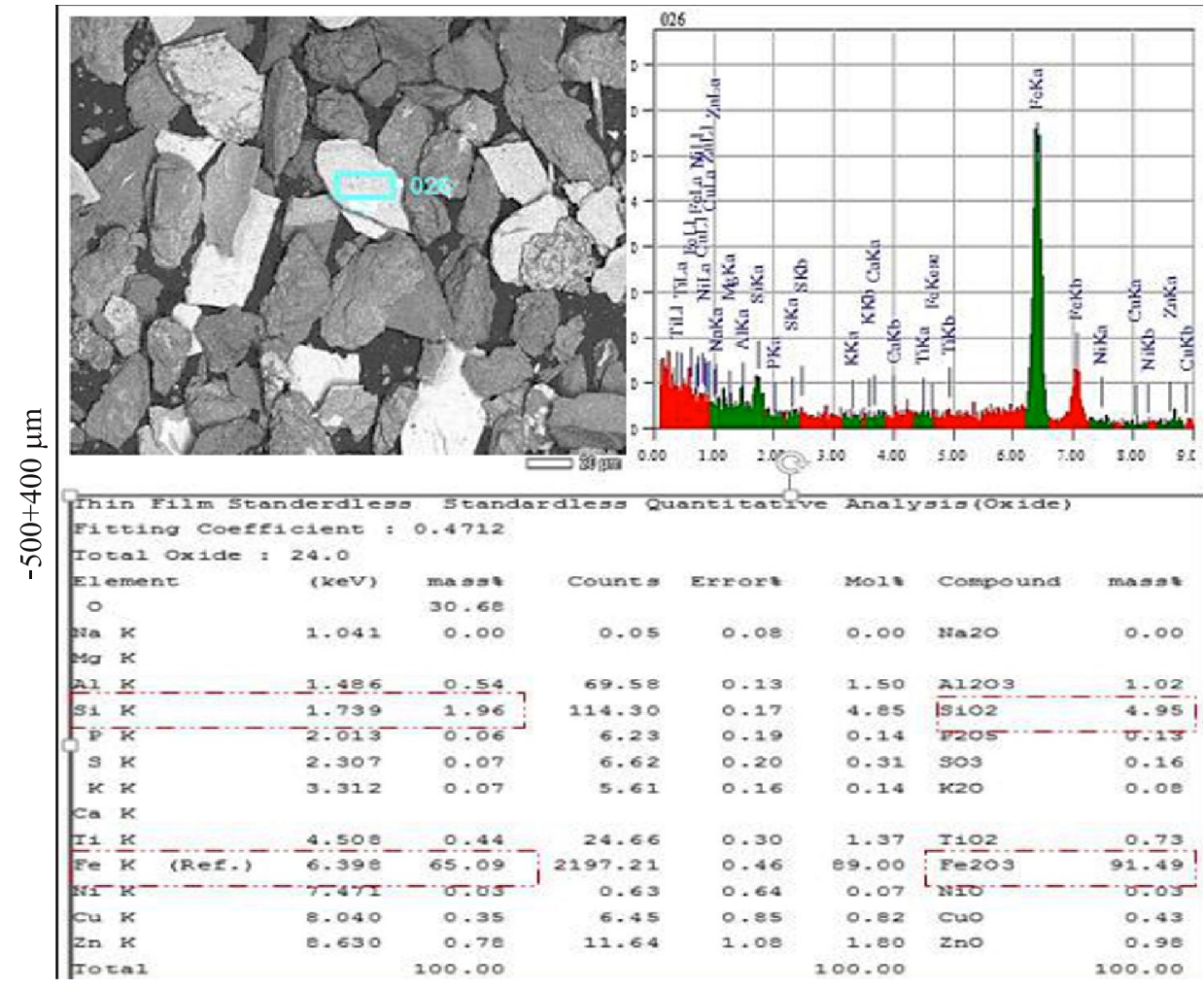

FIG. 5(c). SEM-EDS SPECTRA AND GRADE OF $-300+150 \mu \mathrm{m}$ 


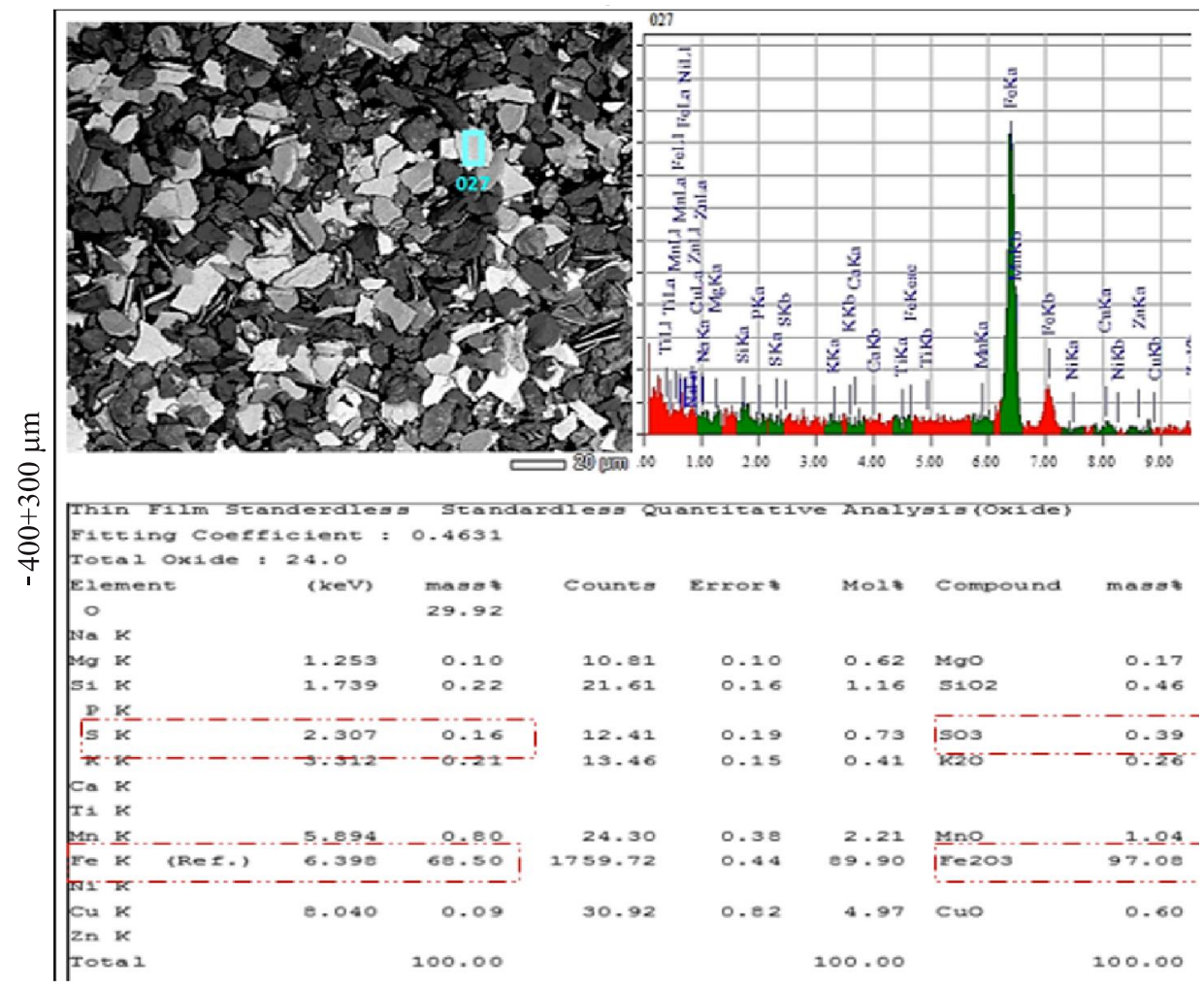

FIG. 5(d). SEM-EDS SPECTRA AND GRADE OF -1500+106 $\mu$

FIG. 5. SEM IMAGES WITH EDS SPECTRA OF VARIOUS SIZE FRACTIONS OF KULLI KOH ORE

\section{CONCLUSION}

In present investigation, the liberation size of two newly discovered iron ore deposits of Pakistan has been successfully investigated through the elemental and image analysis techniques. Results are summarized as follow:

(i) XRF analysis of seven particle size fractions (i.e. $-400+300,-300+200,-200+106,-106+75,-75+45$, $-45+30$ and $-30 \mu \mathrm{m})$ showed that the mesh of liberation of Zard Koh most likely exists at $-75+45$ $\mu \mathrm{m}$. In this particle size, the grade of ore was substantially improved to $60.79 \% \mathrm{Fe}_{2} \mathrm{O}_{3}$, and $\mathrm{FeS}_{2}$ content reduced to $9.02 \%$. Moreover, the increased population and grade of maghemite grains in SEM images and EDS spectra further confirmed the mesh of liberation of Zard Koh iron deposits at $-75+45 \mu \mathrm{m}$ particle size. (ii) XRF analysis of $-500+400,-400+300,-300+150$, $-150+106,-106+45$ and $-45 \mu \mathrm{m}$ demonstrated that the liberation size of Kulli Koh ore exists at $-150+106 \mu \mathrm{m}$ fraction size, wherethe grade of ore was reached to $45.51 \% \mathrm{Fe}_{2} \mathrm{O}_{3}$ and $\mathrm{SiO}_{2}$ content reduced to $5.72 \%$. Interestingly, SEM and EDS analysis of various particle sizes also displayed the majority and grade of hematite grains at $-150+106 \mu \mathrm{m}$ fraction size, indicating the most probable mesh of liberation of Kulli Koh iron deposits.

(iii) The detailed investigation on the liberation size of Zard Koh and Kulli Koh iron ore deposits suggest that the magnetic separation would be more viable techniques for their upgradation. 


\section{ACKNOWLEDGMENT}

Authors wish to express their thanks to Pakistan Steel Mill, Karachi, for providing the samples and the facility of chemical and mineralogical analysis. Authors wish to thank the Organizing Committee of $2^{\text {nd }}$ National Conference on Metallurgy \& Materials, for providing the platform for oral presentation and publishing the paper in Mehran University Research Journal of Engineering \& Technology.

\section{REFERENCES}

[1] Khoso, S.A., Abro, M.I., and Agheem, M.H., "Mineralogical Study of Zard Koh and Kulli Koh Iron Ore Deposits of Pakistan", MehranUniversity Research Journal of Engineering \& Technology, Volume 36, No. 4, pp. 1017-1024, Jamshoro, Pakistan, October, 2017.

Abro, M.I., Mallah, A.H., and Pathan, A.G., "Mineralogical Characterization of Dilband Iron Ore Deposits of Balochistan, Pakistan”, Mehran University Research Journal of Engineering \& Technology, Volume 27, pp. 206-210, Jamshoro, Pakistan, 2008.
Manieh, A.A., "Oolite Liberation of Oolitic Iron Ore, Wadi Fatima, Saudi Arabia”, International Journal of Mineral Processing, Volume 13, pp. 187-192, 1984.

[8] Obassi, E., Gundu, D.T., and Akindele, U., "Liberation Size and Beneficiation of Enyigba Lead Ore, Ebonyi State, South-East Nigeria", Journal of Mineral and Material Characterization Engineering, Volume 3, pp. 125-133, 2015.

Upadhyay, R., Venkatesh, A., and Roy, S., "Mineralogical Characteristics of Iron Ores in Joda and Khondbond Areas in Eastern India with Implications on Beneficiation: Characteristics of Indian Iron Ores”, Resource Geology, Volume 60, pp. 203-211, 2010.

Omran, M., Fabritius, T., and Mattila, R., "Thermally Assisted Liberation of High Phosphorus Oolitic Iron Ore: A Comparison Between Microwave and Conventional Furnaces", Powder Technology, Volume 269, pp. 7-14, 2015.

[11] Ulusoy, U., and Kursun, I., "Comparison of Different 2D Image Analysis Measurement Techniques for the Shape of Talc Particles Produced by Different Media Milling”, Mineral Engineering, Volume 24, pp. 91-97, 2011.

[12] Krishna, S., Patil, M., and Rudrappa, C., "Characterization and Processing of Some Iron Ores of India”, Journal of Industrial Engineering, Volume 94, pp. 113-120, India, 2013.

[13] Muwanguzi, A.J., Karasev, A., and Byaruhanga, J.K., "Characterization of Chemical Composition and Microstructure of Natural Iron Ore from Muko Deposits", Journal of International Scholarly Research Notices: Material Science, pp. 1-9, 2012.

[14] Ogwuegbu, M., Onyedika, G., and Hwang, J.Y., "Mineralogical Characterization of Kuru Cassiterite Ore by SEM-EDS, XRD and ICP Techniques", Journal of Mineral and Material Characterization Engineering, Volume 10, pp. 855-863, 2011. 
[15] Rao, D.S., Kumar, T.V., and Rao, S., "Mineralogy and Geochemistry of a Low Grade Iron Ore Sample from Bellary-Hospet Sector, India and Their Implications on Beneficiation", Journal of Mineral and Material Characterization Engineering, Volume 8, pp. 115-132, 2009 .
[16] Mohanty, J., Jena, M.S., and Paul, A., "Integrated Mineralogical Characterization of Banded Iron Ores of Orissa and Its Implications on Beneficiation”, Journal of Mineral and Material Characterization Engineering, Volume 11, pp. 1133-1142, 2012. 